\title{
The bell-curve drug
}

\section{Choose your poison.}

\section{Jim Kling}

Jonathan poked his head through my office door at the Institute.

"Feeling confident?" We were both Fellows and had known each other since we were Apprentices. I looked up from my computer screen showing the populationdynamics models, and smiled. We had both submitted proposals for the design of a sustainable park ecosystem with human hunters filling the role of top predator. We knew we were the front-runners. I might have stayed for some friendly banter, but I already had plans to see my father in the nursing home.

I took the sky train across town.

"How is your research coming on?" he asked me from the nursing-home bed, attended by a robotic nurse. I described the latest population models. I could see him struggling to comprehend.

"Can I help?" he asked, uncertainly. No, you can't. Not any more.

"It's under control," I said. I could see the relief in his eyes, then the pain.

"I wish...I could."

Aboard the sky train returning to the Institute, I met Rachel for the first time. She didn't have the vapid look of most of the other travellers, on their way to Carnival or some other entertainment. Most stared blankly at a TriVid programme showing on a screen in one corner of the car. I'd written the tragedy subroutine that had been used to create it.

She seemed full of purpose. I took her to be a Fellow at the Institute whom I'd somehow failed to meet before.

I was depressed, and she noticed. She asked why, and I told her about my father.

"It's the Neurypse, of course. He used to work at the Institute, too."

"Neurypse?"

Clearly, she wasn't a Fellow. "JohnsonMerckLilly developed it in the 2010s. It... makes us smarter," I said, deciding against a technical explanation.

"So you're better at your research. But it did that to your Dad?"

I nodded. "There are limits to how long the mind can operate at peak efficiency. After that, it...declines."

"It sounds awful!"

I was taken aback. I swept my arm to indicate the pristine city visible outside the train window. Automated systems produced cheap and abundant energy. Farms produced, packaged and transported food, completely sustainably. Pollution was minimal. Few had to work - aside from those of us at the Institute, of course. "Neurypse made all this possible," I said.

"And your father?"

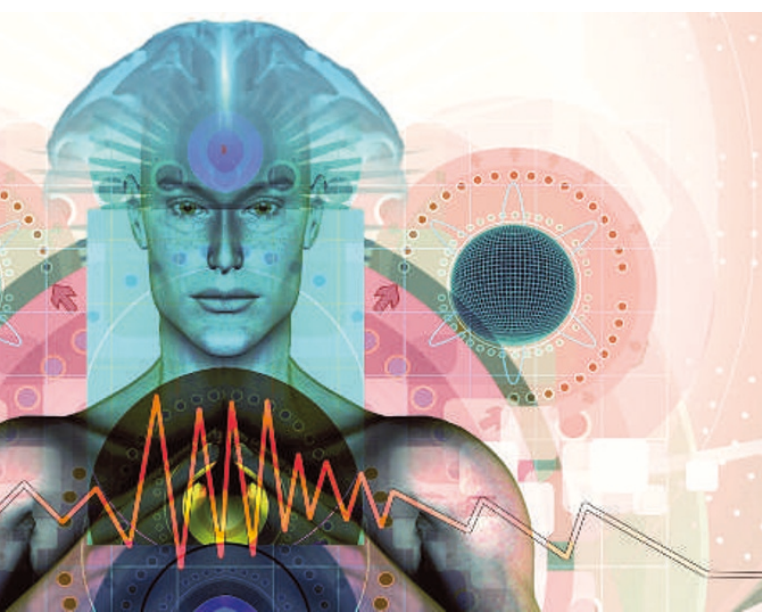

“He’s 62. He’s led a full life." I wondered if I believed it.

"It still sounds awful."

I was about to reply when the train slowed to a stop, and she shocked me by getting up. This was a district of whorehouses and opium dens. She handed me GPS coordinates on a piece of paper. "You should visit me," she said, and left the car amid three shuffling addicts.

The next day, I learned that Jonathan's proposal had won. He was gracious, even offering me a place on his implementation team. I reviewed my proposal and a sick feeling welled up in my stomach when I saw that I had omitted a crucial part of the experimental section. How could I have forgotten it? I thought of my father's blank stare, and felt a gnawing fear.

On the way to visit him a few days later, I saw Rachel again. She boarded at the same station she had exited, with a teenager in tow. His sunken eyes and pallor marked him as an addict. The boy saw the brief look pass between us. He started asking questions, and I told him about my work. His inquisitiveness surprised me. Rachel didn't look at me when I exited.

At the nursing home, my father had taken a turn for the worse. For the first time, he did not recognize me. I left depressed. To clear my head, I decided to visit Rachel. The air cab dropped me off outside the city, in a village surrounded by animal pens and agricultural fields. There were no signs of mechanization. Rachel pushed through the crowd that had gathered to stare.

We walked to a bench near a copse of trees. Rachel told me about the village, how they grew their own food, made clothing, raised animals. She also told me that the boy on the train was her son. He and his friends went to the opium dens frequently, but he stayed longer than most, wasting away for days until she came to retrieve him. "He can't find direction here. He doesn't see the importance of what we're doing," Rachel said.

"Importance?"

"We're reclaiming our humanity," she said. "The Institute's systems can clothe and feed us, but they can't give us that."

I thought about the riders on the sky train, staring mindlessly at the TriVid show created by the subroutine I'd written. I looked around the village with a new interest. Rachel read my expression. "We're relearning everything. We still rely on the Institute to supplement us because we don't have it all down yet. You could help us." She paused briefly, gauging me. "Your father could stay here, too."

That decided it for me. He was wasting away in that grey-walled room, with nothing to do but watch banal TriVid programmes. Here at least he could walk a bit, and watch the goings-on. There would be no end of research to do, and I could stop taking the Neurypse because I wouldn't be fending off competition. A moment later, her son walked up to us, an eager expression on his face.

"May I ask you a question?" he said, looking at me.

"Of course."

"How do I join the Institute?" Jim Kling writes about science and the future (and occasionally the past) from the shadows of a dormant volcano. More details can be found at http://nasw.org/users/jkling. 